Article

\title{
An Ancient Mesiodens Investigated by Cone Beam CT
}

\author{
Laura Maria Beschiu ${ }^{1}$ (D), Bogdan Alin Craiovan ${ }^{2}$, Stefan Popa ${ }^{3}$, Dorel Micle ${ }^{2}$, Lavinia Cosmina Ardelean ${ }^{4, *(D)}$ \\ and Laura Cristina Rusu ${ }^{1}$ (D)
}

1 Department of Oral Pathology, Multidisciplinary Center for Research, Evaluation, Diagnosis and Therapies in Oral Medicine, "Victor Babes" University of Medicine and Pharmacy Timisoara, 2 Eftimie Murgu Sq., 300041 Timisoara, Romania; beschiu.laura@umft.ro (L.M.B.); laura.rusu@umft.ro (L.C.R.)

2 Department of Archaeology, West University of Timisoara, 4 Vasile Parvan Blvd, 300223 Timisoara, Romania; bogdan.craiovan@e-uvt.ro (B.A.C.); dorel.micle@e-uvt.ro (D.M.)

3 National Museum of Banat, 4 Martin Luther Str., 305500 Timisoara, Romania; popa.stefan2811@gmail.com

4 Department of Technology of Materials and Devices in Dental Medicine, Multidisciplinary Center for Research, Evaluation, Diagnosis and Therapies in Oral Medicine, "Victor Babes" University of Medicine and Pharmacy Timisoara, 2 Eftimie Murgu Sq., 300041 Timisoara, Romania

* Correspondence: lavinia_ardelean@umft.ro

Citation: Beschiu, L.M.; Craiovan, B.A.; Popa, S.; Micle, D.; Ardelean, L.C.; Rusu, L.C. An Ancient Mesiodens Investigated by Cone Beam CT. Appl. Sci. 2021, 11, 11703. https://doi.org/10.3390/app112411703

Academic Editor: Cosimo Nardi

Received: 4 November 2021

Accepted: 8 December 2021

Published: 9 December 2021

Publisher's Note: MDPI stays neutral with regard to jurisdictional claims in published maps and institutional affiliations.

Copyright: (c) 2021 by the authors. Licensee MDPI, Basel, Switzerland. This article is an open access article distributed under the terms and conditions of the Creative Commons Attribution (CC BY) license (https:// creativecommons.org/licenses/by/ $4.0 /)$.

\begin{abstract}
This article presents the complex case study of an ancient skeleton presenting a maxillary supernumerary tooth (mesiodens). The skeleton was found in an archaeological site in the western part of Romania and was dated back to the Eneolithic period, some 5500 years ago. The aim of this article is to analyze the mesiodens and the jaws in light of current knowledge regarding anomalies of dental development of past and present-time populations. The cranial remains were investigated from an orthodontic perspective through inspection and cone beam computed tomography (CBCT) scan. The occlusion was analyzed according to Angle's classification and observations were made regarding the presence of calculus, dental wear, presence of caries, bone loss and ante-mortem tooth loss. Observations were made regarding tooth dimensions and comparisons were made with modern population. In this specific case, the mesiodens caused minimum disruption within the upper dental arch and the occlusion. Additionally, it did not have any negative impact on the adjacent teeth or cause any other complication. Judging by the analysis of the jaws, the presence of the mesiodens had little impact on the overall oral health of the person. As suggested by other findings in the scientific literature, the mesiodens is an anomaly found throughout all historical periods, from the oldest archaeological sites to present day.
\end{abstract}

Keywords: mesiodens; orthodontics; cone beam CT; paleoimaging; archaeology; eneolithic; paleopathology

\section{Introduction}

\subsection{Archaeological Background}

The present article is focused on assessing the cranial remains, particularly the jaws, presenting a mesiodens, belonging to a skeleton dated back to the Eneolithic period, found in the archaeological site of Mosnita Veche-Obiectiv 16 "Dealul Salas", near Timisoara, in the western part of Romania. The Eneolithic period, also known as the Chalcolithic or the Copper Age, is the chronological sequence between the Neolithic and the Bronze Age, when copper was used alongside flint for manufacturing artefacts [1]. From a chronological standpoint, the Eneolithic period roughly covers the time span between 4500-2800 cal BC (calibrated years before Christ), this chronology being valid for our geographical area of interest. During the excavation, three well preserved graves have been uncovered, as well as a few heavily disturbed graves. One of the well preserved skeletons discovered, coded as "Individual 1", presented a mesiodens.

The grave goods found in the burial pit consisted of two clay pots, a flint blade and several flint scrapes. 
Based on the typological characteristics of the two clay pots discovered within the grave pit, as well as the characteristics of the burial ritual used, the findings belong to the Bodrogkeresztúr cultural group [2], which extended over large parts of present day Hungary and the western part of Romania, during the Middle Eneolithic period [3]. Given the current state of research, we can assume that the individuals who belonged to the Bodrogkeresztúr culture lived in small sized settlements, and their economy was mainly based on agriculture, animal husbandry and hunting, as well as pottery production and copper metallurgy [3,4]. Regarding the absolute chronology, to this day research papers still debate on the subject, as some prefer the time period set between 4300-3750 cal BC [5], while others lean towards the 4200-3800 cal BC time frame [6].

The present findings support the idea that we are dealing with the presence of a small sized Bodrogkeresztúr cemetery, within the boundaries of the archaeological site known as Mosnita Veche 16-“Dealul Salas". In the western part of Romania, similar graves were found in 2015, 2016 and 2017, as the result of archaeological excavations performed on the site "Pecica Est" (Arad county) [7]. At the time of writing the present paper, the archaeological excavation is still underway.

\subsection{Supernumerary Teeth}

According to the literature, supernumerary teeth, formed in addition to the normal dentition, can be single or multiple, unilateral or bilateral, erupted or impacted and located in the maxilla and/or the mandible. The most common type is the mesiodens, located between the central incisors [8], most frequently conical in shape [9-12].

The etiology of supernumerary teeth has been previously explained through various theories, among them, the phylogenetic reversion or atavism, the hyperactivity of the dental lamina or a combination of genetic factors [13].

The genetic etiology is supported by the fact that they are more frequently found in relatives of affected individuals than the general population [14-17]. However, developmental factors must also be considered, such as hyperproductivity of the dental lamina and dichotomy of tooth germs, proven by in vitro experiments $[8,14,18]$.

The presence of supernumerary teeth in present-day population is a quite rare anomaly, according to the literature $[8,10]$. The prevalence of supernumerary teeth varies between $0.1-3.8 \%$ of the present-day population and is more common in permanent dentition [9], but it could also be overlooked by parents in the temporary dentition if there are no obvious signs of misalignment of the teeth [19]. In $82 \%$ of the cases, it is located in the maxilla, specifically in the premaxilla region, followed by maxillary third molars, premolars, canines and lateral incisors, with only rare cases reported in the mandible $[8,10,14]$. Supernumerary teeth are usually related with larger teeth than in control groups and appear more frequently in men [20]. In case of a mesiodens, the upper and lower incisors show the greatest differences, i.e., the upper central incisors adjacent to the supernumeraries show a more pronounced barrel shape from the labial view [21].

Sexual dimorphism is commonly reported by authors, with men being affected 1.9 times more frequently than women [8]. In addition, the prevalence of supernumerary teeth seems to be higher in Mongoloids and African Americans [14,15].

High frequency is related to specific pathologies such as Gardiner's syndrome, cleidocranial dysostosis, chondroectodermal dysplasia, trichorhinophalangeal syndrome or cleft lip and palate [22].

The complications that can arise in case of supernumerary teeth vary greatly, including: no effect; crowding, malposition; eruption disturbances, while the underlying permanent teeth usually erupt spontaneously following the removal of un-erupted supernumeraries [23]; the development of follicular cysts; caries and loss of vitality of adjacent teeth; gingivitis, periodontitis; occlusal interferences; and neuralgic manifestations [11,24]. According to available data, $75 \%$ of the mesiodens are impacted $[9,16]$. 
Impacted supernumeraries may be detected by imaging techniques, such as panoramic, occlusal, periapical radiographs or cone beam computed tomography (CBCT), which provides more accurate assessments [12].

The aim of this complex case study is to analyze the mesiodens and the jaws of "Individual 1" from an orthodontic perspective, including CBCT scans to further assess the cranial remains. The results were analyzed in light of current knowledge regarding dental development anomalies of past and present-time populations, aiming to further create a database to compare the frequency and pattern of this pathology in ancient versus modern times.

\section{Materials and Methods}

Within the boundaries of the archaeological site known as Mosnita Veche 16-“Dealul Salas", three undisturbed graves, containing six well preserved skeletons, were found.

The skeletal remains presenting the mesiodens were found buried in the same grave pit with another skeleton. In order to properly document the grave, the two skeletons were each assigned an indicative. The skeleton on the right hand side, presenting the mesiodens, male, was named "Individual 1", while the one on the left hand side, female, was attributed the name "Individual 2" (Figure 1). The deceased were buried in a slightly oval shaped pit, both of them orientated on a NE-SW axis, with their heads pointed towards the North-East. "Individual 1" was buried in a crouched position, on his right side, with his head facing "Individual 2" and his left hand placed on top of the humerus of "Individual 2". "Individual 2" was placed on her back, slightly arched, with the legs bent towards the South-West and the head facing away from "Individual 1" and oriented towards the South-West. Her right hand was placed on the stomach, while the left arm was placed over "Individual 1". The arrangement of the bodies gives the impression that the two individuals were embracing each other, or to be precise, "Individual 1" was embracing "Individual 2", which is the reason for naming them "The Eneolithic Lovers".

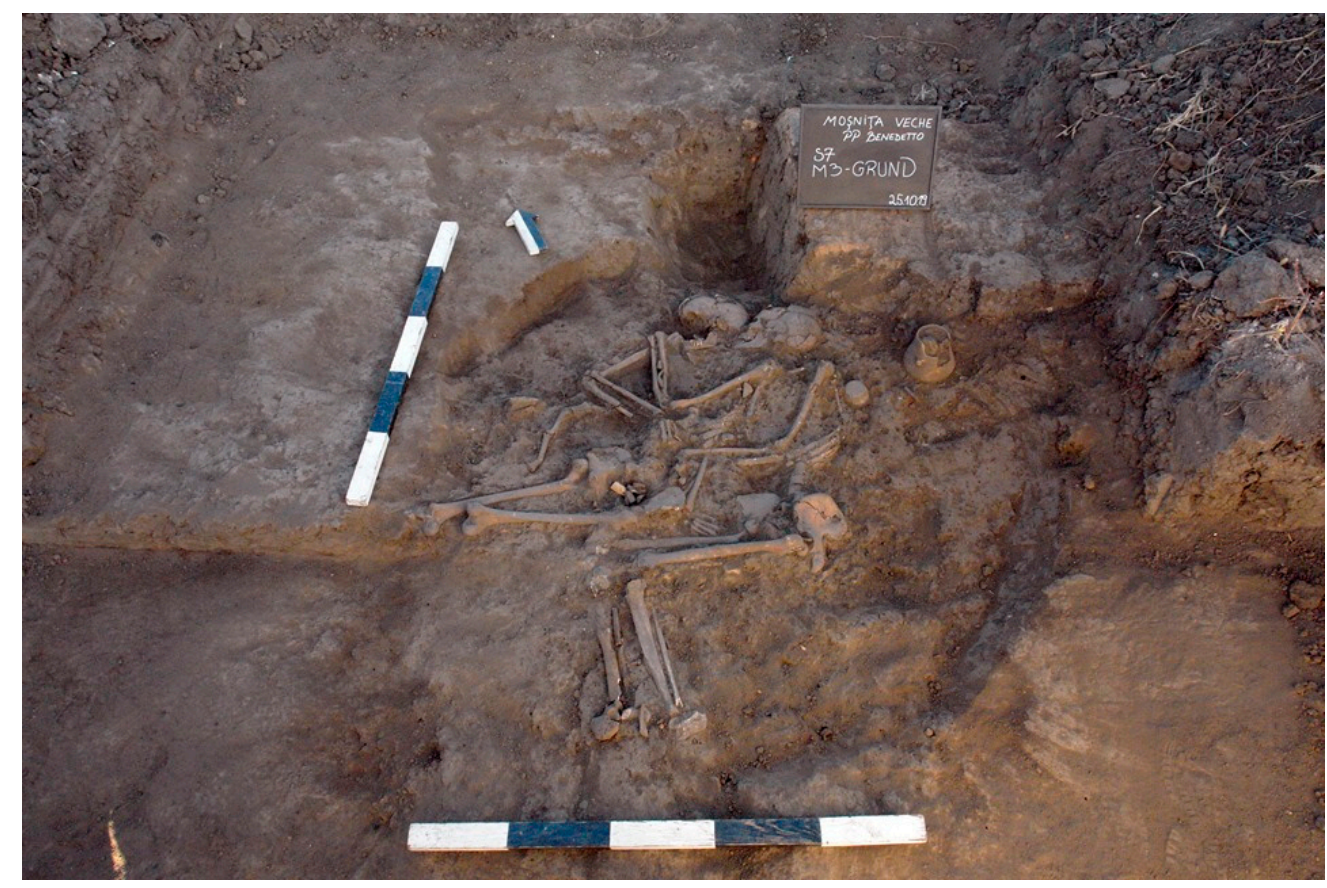

Figure 1. The two skeletons upon being discovered.

The sex of the two individuals has been determined using morphological traits of the os coxae and the skull after the methodology proposed by Buikstra and Ubelaker [25]. Age of death has been determined using the auricular surface of the ilium, according to 
Lovejoy [26] and the dentition wear, according to White and Folkens [27]. Stature has been estimated using the Sjøvold method [28].

The jaws of "Individual 1", presenting a mesiodens, have been inspected macroscopically, from an orthodontic perspective. The mandible has been restored having the socket contour of the lower right central incisor (LR1) as guideline, as well as its internal and external basal margins.

The maxilla and the mandible have been assessed both separately and in occlusion. The presence of caries, hypoplasia, tooth wear, abscesses, calculus and periodontal disease have been analyzed for each tooth. Non-occlusal attrition and interproximal attrition have also been assessed, as well as dental crowding within the arch. The tooth wear has been coded according to Smith and the amount of calculus present on each tooth was coded according to Brothwell [25].

The occlusion has been assessed according to Angle's classification. The dental arches were placed in occlusion based on the attrition facets present, having the maximum number of interdental contacts as guideline.

The mesiodens has been analyzed from the point of view of its dimensions and position relative to the adjacent teeth and also within the dental arch and in occlusion. The measurements of teeth dimensions have been carried out using a digital caliper.

CBCT imaging has been chosen to further asses the maxilla bone and teeth, as it provides precise and accurate information on normal and pathologic conditions such as odontomas, supernumerary teeth, developmental anomalies and traumatic injuries. Among its advantages, the following are of most importance: 3D imaging of dental structures, easy data transfer, less imaging time, and lower ionizing radiation dose compared to CT $[29,30]$.

The 3D images of the oral and maxillofacial structures acquired by CBCT, on a high resolution, using an extraoral imaging scanner, enable a better understanding of the anatomical structures, pathologic conditions, developmental anomalies, and traumatic injuries, the technique being especially useful in determining the supernumerary and impacted teeth position [26,31].

\section{Results}

\subsection{Sex, Stature and Age}

At the inspection it has been noted that the two skeletons were well preserved. Their crania were broken but most of the pieces were present, while the cranium of "Individual 2 " has been dislodged and rotated to 180 degrees, probably due to ground pressure, as all other bones seem to be found in more or less the same position as they would have been at the time of their deposition (Figure 1).

"Individual 1" (on the right hand side) has been estimated at $159.2 \pm 4.32 \mathrm{~cm}$ and was determined to be male, around 30-35 years old.

"Individual 2" (on the left hand side) has been estimated at $164.6 \pm 4.52 \mathrm{~cm}$ and was determined to be female, around $40-45$ years of age (Figure 1).

\subsection{Inspection of the Jaws}

Only "Individual 1" (Figure 1) (male according to the anthropological report) presented a mesiodens. The further presented data refer to the jaws belonging to "Individual 1 ". His maxilla and mandible have been coded as 1 for completeness of a bone, according to Buikstra and Ubelaker [25].

\subsubsection{The Maxilla}

As shown in Figure 2, the maxilla presented with the following teeth: the upper right premolars (UR5, UR4), the upper right canine (UR3), the mesiodens, the upper left central incisor (UL1), the upper left canine (UL3), both upper left premolars (UL5, UL4) and the upper left first molar (UL6). The alveoli of the upper right lateral incisor (UR2), that of the upper right central incisor (UR1) and of the upper left lateral incisor (UL2) have been 
well preserved and had undergone no bone remodeling showing that the teeth had clearly been lost postmortem. Both right and left tuberosities were broken and the molars missing, except for the upper left first molar (UL6).

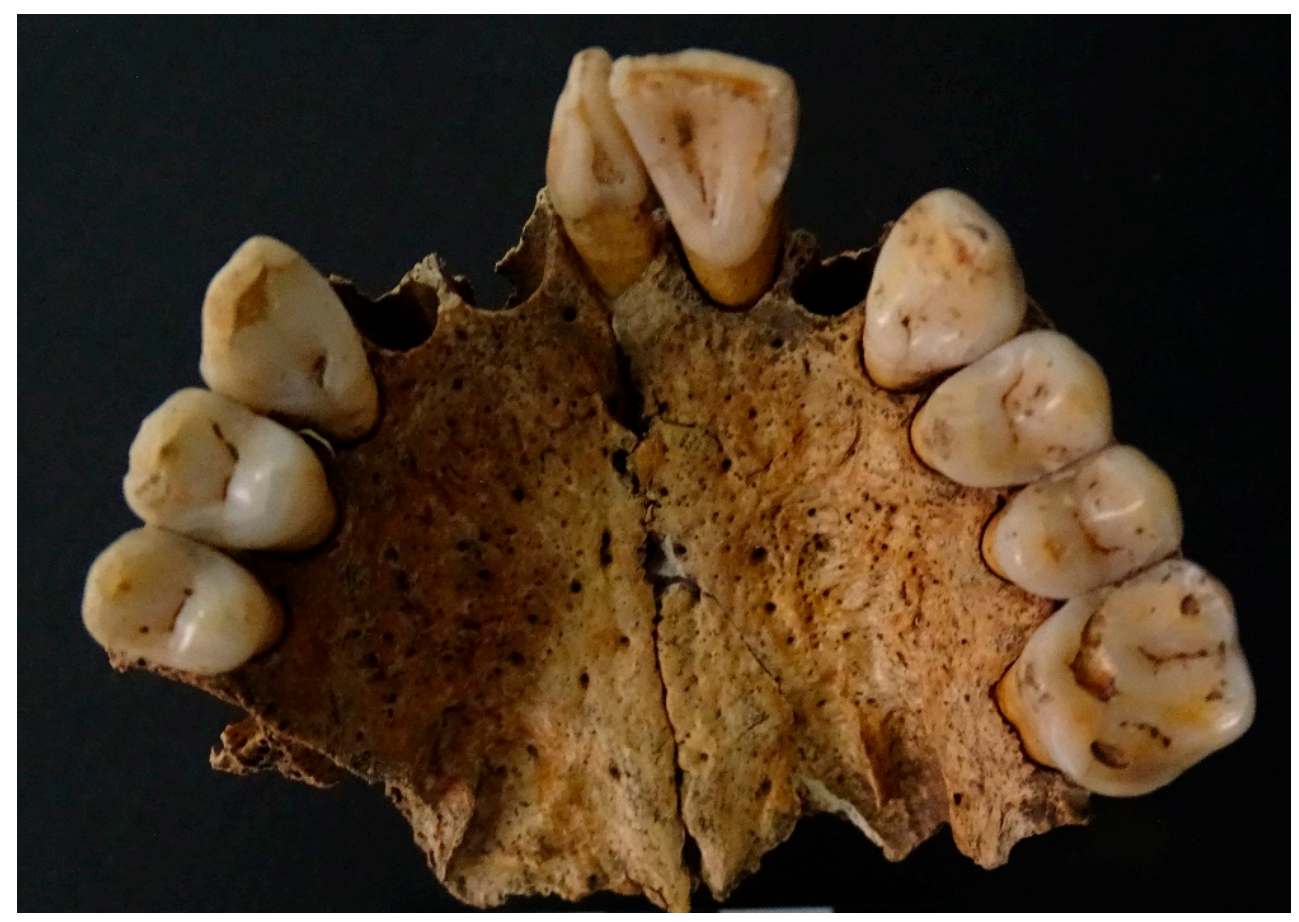

Figure 2. Occlusal view of the maxilla and the present teeth. Abrasion facets present on all teeth. Carious lesions absent.

The teeth are well aligned, except for the mesiodens, which had a 90-degree rotation, with its buccal side towards the upper left central incisor (UL1). The position of the mesiodens coincides with the maxillary midline suture, adjacent to the UL1 on the left and to the UR1 on the right, the latter being lost post-mortem. It caused no asymmetry in the upper arch. The lower midline also coincides with the mandibular symphysis as well as with the mesiodens.

The UL1 and the UR1 roots presented with an approximately 20 degree inclination towards the distal side because of the presence of the mesiodens. The inclination of the UR1 has been confirmed radiologically by the inclination of its socket.

General minor to moderate alveolar bone recession is present, but it has also to be considered that some interdental alveolar margins could have been damaged during the excavation of the cranium, especially the buccal alveolar bone covering the root of the upper left central incisor (UL1).

\subsubsection{The Mandible}

The mandible has been broken along the symphysis region, with the fracture line going through the socket of the lower right central incisor (LR1) (Figure 3). 


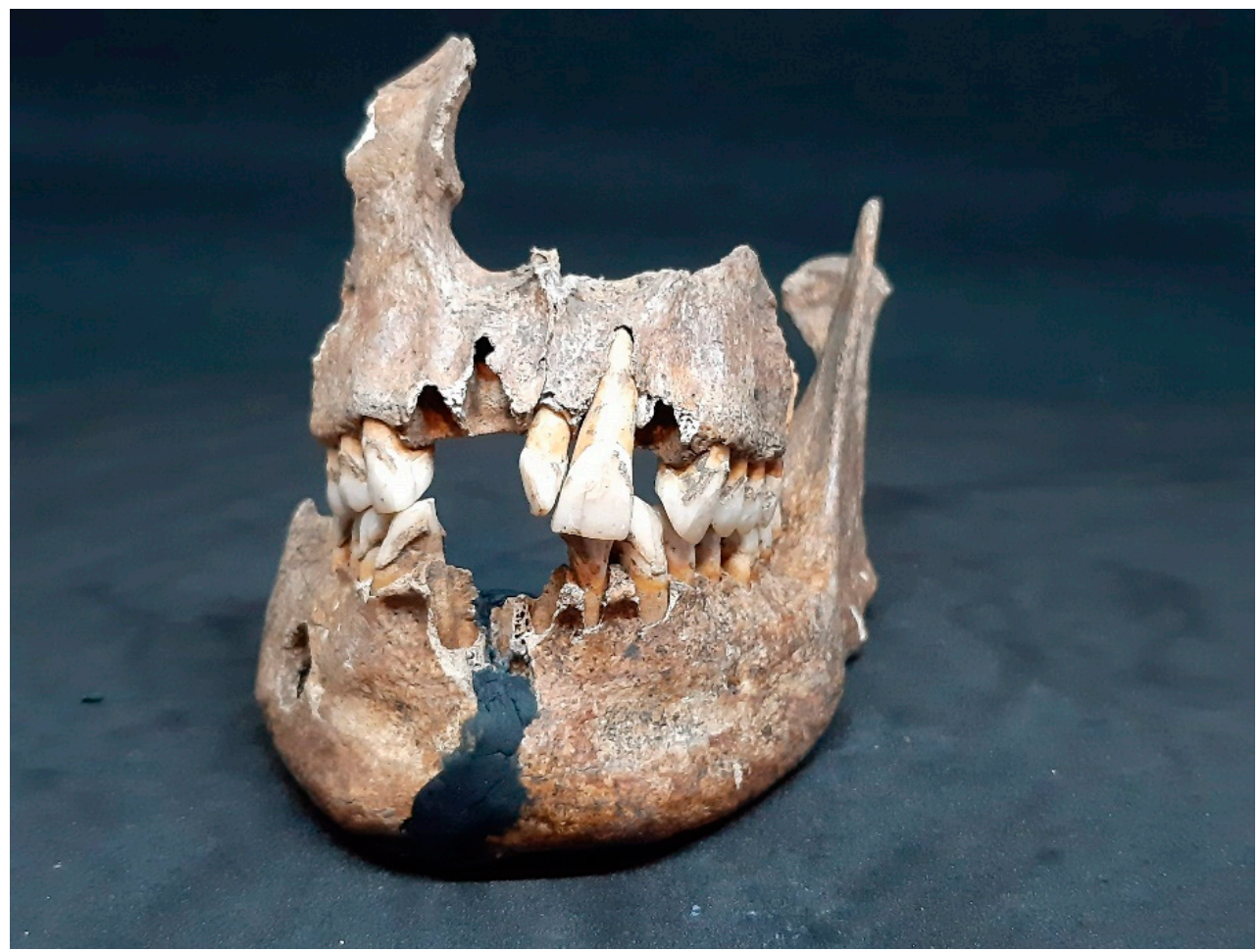

Figure 3. The maxilla and the reconstructed mandible.

Both the base of the mandible and the ramus display no abnormalities. The mandibular symphysis, the mentoneal protuberance, as well as the left side coronoid process and condyle (the right side coronoid process and condyle are unobservable as they were damaged and could not be assessed) are all within normal appearance.

The lower left central incisor (LL1), as well as the lower right central (LR1) and lateral incisors (LR2) were missing, as was the lower right wisdom tooth (LR8), all of them being lost post-mortem.

The present lower teeth are well aligned and the sockets of the missing lower teeth show a normal root position; hence, the missing teeth were most-likely well aligned as well.

\subsubsection{The Teeth}

The total number of observable teeth is 21 (Table 1), with six anterior teeth being lost post-mortem, while the rest belong to parts of the jaws that were damaged and could not be retrieved.

Both the upper and lower teeth lack any sign of caries or any type of enamel defects, such as hypoplasia or decalcification (Table 1). They display evidence of moderate attrition of the occlusal and incisal surfaces with patches of dentine being exposed around the cusps and the incisal margins, but the enamel rim is not destroyed in any of the teeth. The interproximal attrition facets are also moderate throughout the dental arches (Figure 2).

All teeth have moderate calculus deposits in the cervical region, moreso on the labial surface than on the lingual, with no major differences between the right side and the left side, suggesting a balanced, normal mastication pattern of the individual (Table 1). 
Table 1. Main characteristics of the teeth.

\begin{tabular}{|c|c|c|c|c|c|c|c|}
\hline Tooth & Presence & Development & Wear & Caries & Abscess & Calculus & Hypoplasia \\
\hline UR8 & Unobservable, region damaged & - & - & - & - & - & - \\
\hline UR7 & Unobservable, region damaged & - & - & - & - & - & - \\
\hline UR6 & Unobservable, region damaged & - & - & - & - & - & - \\
\hline UR5 & Present & complete & 3 & 0 & 0 & 2 & 0 \\
\hline UR4 & Present & complete & 3 & 0 & 0 & 2 & 0 \\
\hline UR3 & Present & complete & 4 & 0 & 0 & 2 & 0 \\
\hline UR2 & Missing, lost post-mortem & - & - & - & - & - & - \\
\hline UR1 & Missing, lost post-mortem & - & - & - & - & - & - \\
\hline Mesiodens & Present & complete & 4 & 0 & 0 & 1 & 0 \\
\hline UL1 & Present & complete & 4 & 0 & 0 & 1 & 0 \\
\hline UL2 & Missing, lost post-mortem & - & - & - & - & - & - \\
\hline UL3 & Present & complete & 3 & 0 & 0 & 2 & 0 \\
\hline UL4 & Present & complete & 3 & 0 & 0 & 2 & 0 \\
\hline UL5 & Present & complete & 3 & 0 & 0 & 2 & 0 \\
\hline UL6 & Present & complete & 4 & 0 & 0 & 2 & 0 \\
\hline UL7 & Unobservable, region damaged & - & - & - & - & - & - \\
\hline UL8 & Unobservable, region damaged & - & - & - & - & - & - \\
\hline LL8 & Present & complete & 3 & 0 & 0 & 2 & 0 \\
\hline LL7 & Present & complete & 3 & 0 & 0 & 2 & 0 \\
\hline LL6 & Present & complete & 4 & 0 & 0 & 2 & 0 \\
\hline LL5 & Present & complete & 3 & 0 & 0 & 2 & 0 \\
\hline LL4 & Present & complete & 3 & 0 & 0 & 2 & 0 \\
\hline LL3 & Present & complete & 3 & 0 & 0 & 2 & 0 \\
\hline LL2 & Present & complete & 3 & 0 & 0 & 2 & 0 \\
\hline LL1 & Missing, lost post-mortem & - & - & - & - & - & - \\
\hline LR1 & Missing, lost post-mortem & - & - & - & - & - & - \\
\hline LR2 & Missing, lost post-mortem & - & - & - & - & - & - \\
\hline LR3 & Present & complete & 3 & 0 & 0 & 2 & 0 \\
\hline LR4 & Present & complete & 3 & 0 & 0 & 2 & 0 \\
\hline LR5 & Present & complete & 3 & 0 & 0 & 2 & 0 \\
\hline LR6 & Present & complete & 4 & 0 & 0 & 2 & 0 \\
\hline LR7 & Present & complete & 4 & 0 & 0 & 2 & 0 \\
\hline LR8 & Unobservable, region damaged & - & - & - & - & - & - \\
\hline
\end{tabular}

On inspection, as well as radiographically, there is no apical pathology noted and there is no sign of abscesses.

The crowns and roots of all teeth present with normal morphology. The mesio-distal dimensions of the present frontal teeth crowns are given in Table 2. There is no barrel shape appearance of the UL1, contrary to Brook's findings [21].

Table 2. Mesio-distal dimensions of the incisors and canines present (mm).

\begin{tabular}{cc}
\hline Tooth & Mesio-Distal Diameter $(\mathbf{m m})$ \\
\hline UL1 & 9.13 \\
UL3 & 7.82 \\
UR3 & 7.96 \\
LL3 & 7.18 \\
LR3 & 7.11 \\
\hline
\end{tabular}

Attrition (according to Smith): Code 1 stands for unworn (no dentin exposure); Code 2 stands for point or hairline of dentine exposure/moderate cusp removal; Code 3 stands for dentine line of distinct thickness/moderate dentine patches; Code 4 stands for moderate dentine exposure no longer resembling a line/at least one large dentine exposure on one cusp; Code 5 stands for large dentin area with enamel rim complete/two large dentin areas; Code 6 stands for large dentin area with enamel rim lost on one side or very thin enamel only/dentinal areas coalesced; Code 7 stands for enamel rim lost on two sides/full dentin 
exposure, loss of rim at least one side; Code 8 stands for complete loss of crown/severe loss of crown height [25].

Calculus (according to Brothwell): Code 1 stands for small amount of calculus present; Code 2 stands for moderate amount of calculus present; Code 3 stands for large amount of calculus present [25].

\subsubsection{The Occlusion}

The occlusion has been assessed according to the Angle classification, hence the individual presented with a normal occlusion, i.e., both right and left side class I canine relationship and class I molar relationship on his left side (his upper right first molar was missing, so that the lateral occlusion on his right side could not be assessed under the same criteria). Judging by the teeth present, it can be presumed that the posterior teeth presented with normal occlusion (Figures 4 and 5).

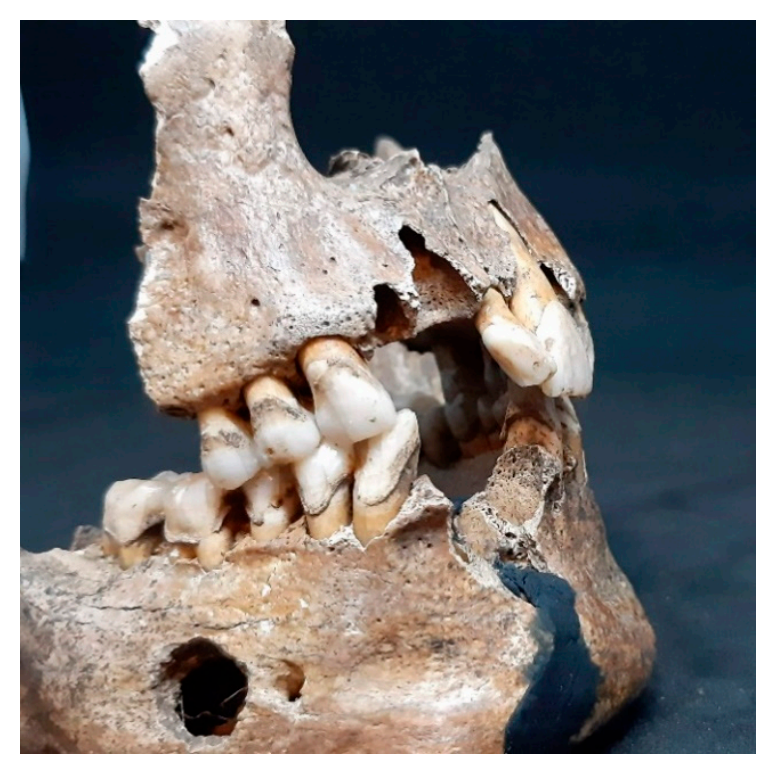

Figure 4. Right side view. Canine class I occlusion. Normal occlusion of the canines and premolars, presence of calculus and moderate alveolar bone recession.

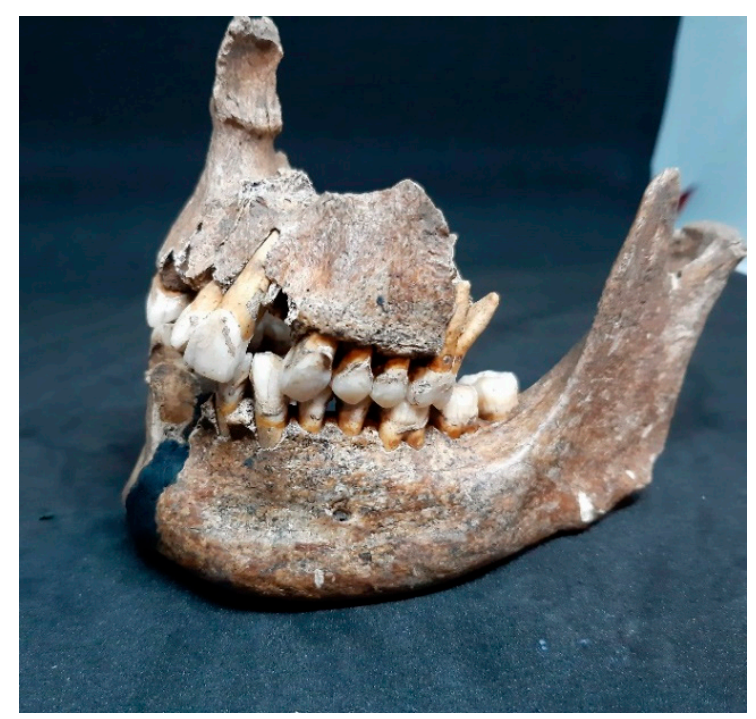

Figure 5. Left side view. Canine and molar class I occlusion.

In the vertical plane, the overbite measured $3 \mathrm{~mm}$ and is rather normal, whereas in the sagittal plane, the overjet is increased $(5 \mathrm{~mm})$, because of the presence of the mesiodens. 


\subsubsection{The Mesiodens}

The position of the mesiodens coincides with the maxillary midline suture, adjacent to the UL1 on the left and to the UR1 on the right, the latter being lost post-mortem. It has caused no asymmetry in the upper arch. The lower midline also coincides with the mandibular symphysis as well as with the mesiodens.

The mesiodens is fully-formed but small-scale, with the crown mimicking the incisor form, fully erupted into occlusion (Figure 6). Its mesio-distal dimension is $5.05 \mathrm{~mm}$ and the dimension from the cement-enamel junction (CEJ) to the incisal margin on the buccal side is $8.99 \mathrm{~mm}$ (Table 3). Minor damage to the alveolar margin has exposed the cement of the root at the CEJ and this also appears normally formed. It has a 90-degree rotation, with its buccal side towards the UL1 and its palatal side towards the UR1, the latter being lost post-mortem (Figure 6).

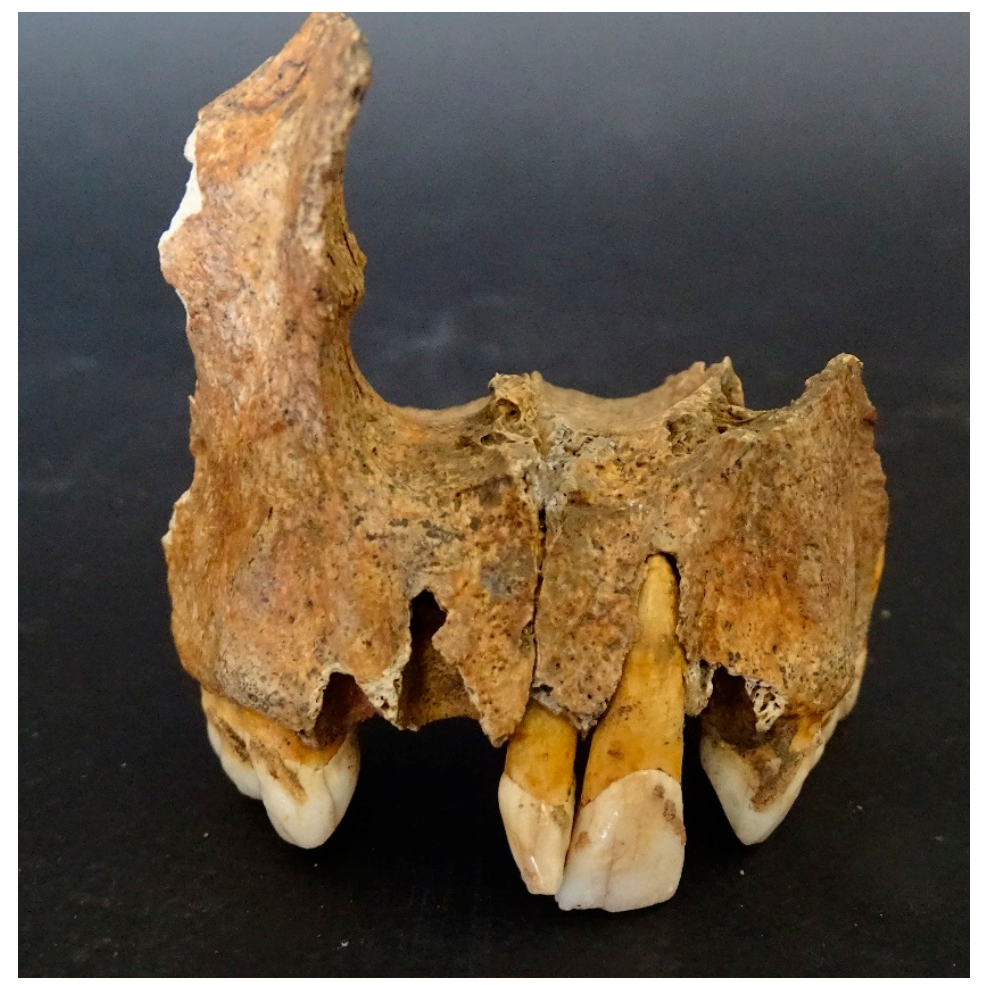

Figure 6. Frontal view of the mesiodens and the maxilla. 90-degree rotation of the mesiodens and slight mesial inclination of the UL1.

Table 3. Dimensions of the mesiodens (mm).

\begin{tabular}{cc}
\hline Dimension & $\mathbf{m m}$ \\
\hline Mesio-distal diameter & 5.05 \\
\hline $\begin{array}{c}\text { Maximal crown length } \\
\text { (from CEJ to incisal margin) }\end{array}$ & 8.99 \\
\hline
\end{tabular}

\subsection{The CBCT Scan}

The CBCT scan provided the radiological confirmation of the fact that there are no other supernumerary teeth present (Figures 7 and 8). 


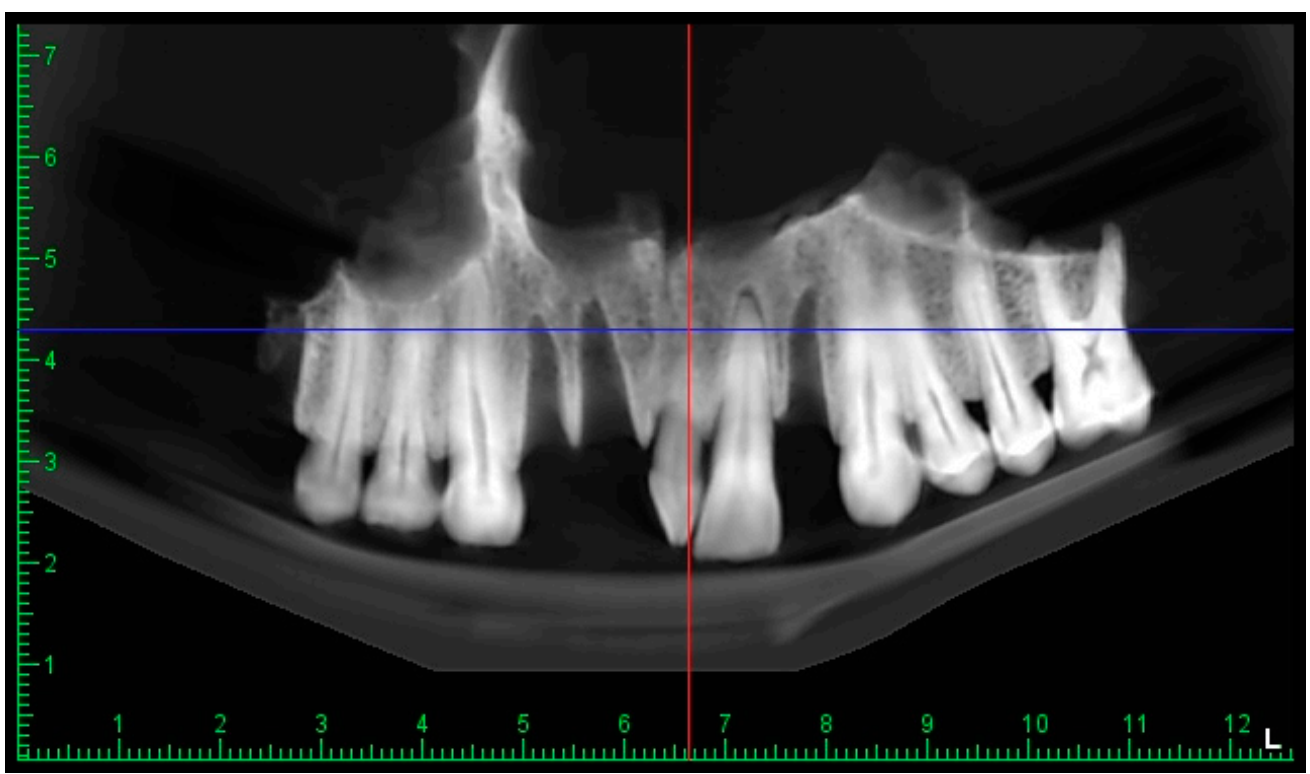

Figure 7. CBCT scan of the maxilla.

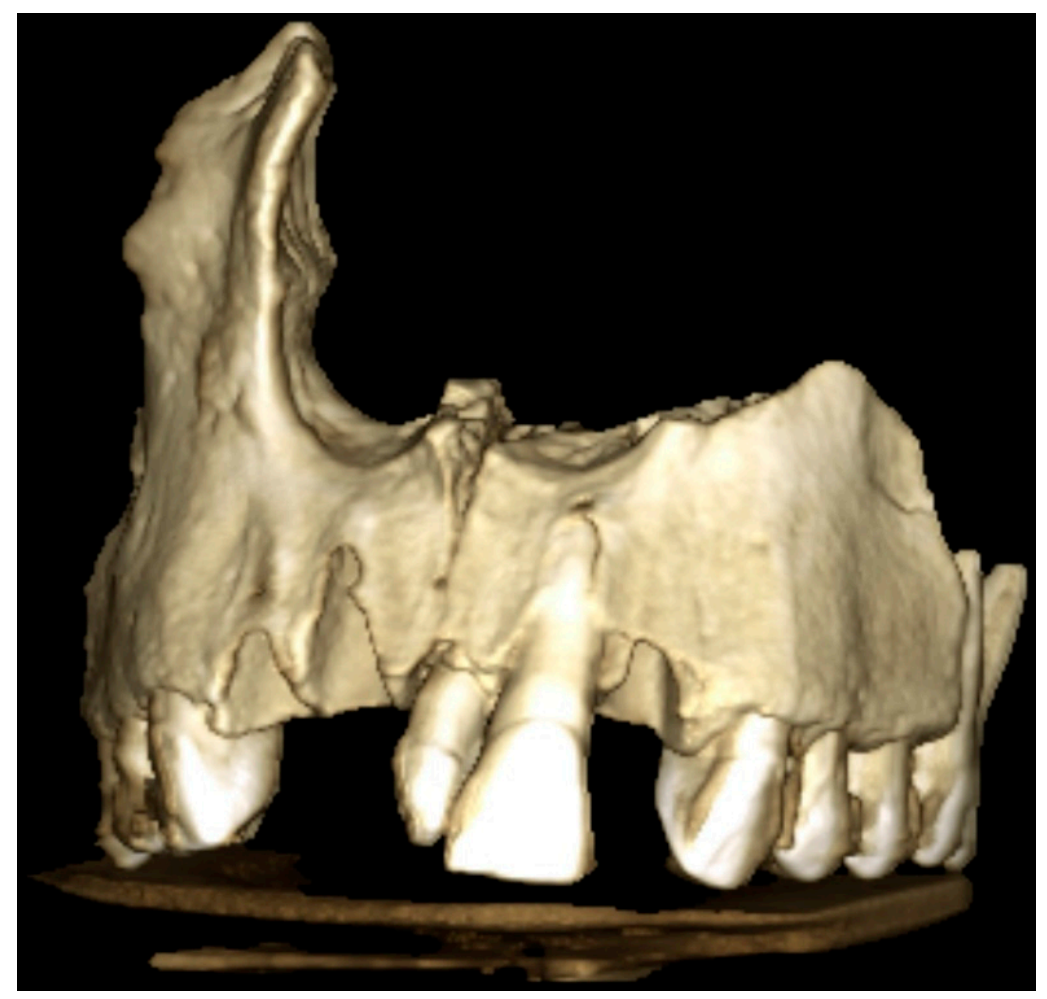

Figure 8. The CBCT scan of the maxilla, confirming the more severe bone recession on the left side.

The CBCT scan (Figures 7 and 8) shows normal bone and root contour and no apical pathology on any of the teeth present. There is evidence of minor to moderate marginal bone loss, especially around the upper left premolars (UL4, UL5) and the upper left first molar (UL6), probably due to periodontal disease.

\section{Discussion}

4.1. Tooth Development and Why Tooth Anomalies of Number, Size and Structure Are Connected

Generally speaking, tooth development is an intricate mechanism that involves multiple factors, both genetic and environmental, and in order to fully comprehend the picture 
of developmental anomalies of teeth we must look into the mechanisms and explanations that, in time, were given for these processes.

In 1945, Dahlberg [32] modified Butler's Field Theory for the human dentition, which focused on the evolution and development of dentition and tried to explain different patterns of agenesis describing four morphological fields (incisors, canines, premolars and molars). The more mesial tooth in each field was proposed to be the more stable tooth and was rarely missing, while the teeth at the end of each field were more unstable and hence, were more frequently absent [33]. Indeed, most studies have shown that the most affected teeth by agenesis are the lower second premolars, the upper lateral incisors and the third molars, i.e., the most distal element of a field [21,26,34,35].

Sharpe puts forward the concept of an odontogenic homeobox to explain how different teeth are initiated in different parts of the oral cavity in response to molecular cues and the expression of specific groups of homeobox genes [36]. Mitsiadis proposed that the previous models could all be incorporated into a single concept to explain dental patterning [37] and Brook [21] also proposed a multifactorial model that encompasses genetic, epigenetic and environmental causes and also that there is an underlying continuous distribution of tooth and size, with thresholds determining hypodontia and supernumeraries. Hence, both hypodontia and supernumerary anomalies have to be considered, because they are interlinked [21,38]. Going forward with his explanations, Brook suggests that even if a single mutation of one gene or one major environmental insult has been identified in a patient with a dental anomaly, a careful phenotype analysis will often reveal variation between affected individuals in the same family, between dentitions in the same individual and even between different teeth in the same dentition. Thus, the same gene or environmental factor, depending on all other intricate mechanisms that happen during the dental development, will have a different phenotype expression [21]. At the same time, same or very similar clinical phenotype of whether anomalies of tooth number or structure, can arise from different aetiologies, both environmental and genetic. More than three hundred genes have been found to take part in the tooth development, while, at the same time, crucial processes need to take place between the mesenchymal and epithelial cells, and disturbances of these factors will determine the presence or absence, the size and the shape of the individual tooth [21].

Studies on mice presenting with supernumerary teeth show that these supernumeraries may develop from vestigial tooth buds that did not undergo apoptosis as they would normally have done. They also presented with an aberrant thickening of the oral epithelium [21].

As the development of number, size and structure of teeth is interconnected, so are their anomalies and therefore, they appear clinically together in the same dentition.

\subsection{Is Hypodontia More Frequent in Present-Day Populations and Were Supernumeraries More Frequent in the Past?}

The introduction of more processed foods over time, is believed to have had an impact on the size of human jaws and masticatory system, as less and less effort is required for mastication, leading to smaller jaws and possibly fewer teeth, as humans evolve [39].

Another theory hypothesizes that the last tooth of each class are "vestigious bodies" that became obsolete during the evolution process [33].

In present-day populations, hypodontia is reportedly the most common dentofacial malformation in humans, with prevalence rates varying between $1.6-10.1 \%$, while Europeans and Australians are more affected than North Americans [33,40,41].

Studies looking into the etiology of hypodontia over time have come up with different answers. For instance, Mattheeuws et al. found that hypodontia had increased since 1957 [42], whereas Heuck Henriksson et al. found that there was no increase of hypodontia of the third molar from the medieval period until present [43]. Of course, it has to be considered that differences between the different type of populations are probable, so the more specimens assessed, the wider database available, in order to have a clearer picture of the phenomenon. 
However, the scarcity of complete jaws and crania from archaeological records, makes it difficult to create relevant statistical records of dental pathology regarding different historical periods of time. In this view, we would like to emphasize the importance of acknowledging the presence of any supernumerary teeth in old crania, in order to create a database and compare their prevalence with present-day cases.

Regarding geminated and fusioned teeth, there is a report of a 4000 year old mummy from ancient Egypt presenting with a fusioned right maxillary incisor and a geminated left maxillary incisor [44] as well as a few more recent findings [45].

Records of supernumerary teeth from all historical periods are available, but the prevalence of supernumeraries in the past is difficult to estimate because of the practical aspects associated with the uncovering of human remains, i.e., the lack of a large study sample and also the degradation and breakage to which skeletons are subjected to, while in the ground and while being uncovered.

The oldest specimen cited in the literature is a 1.7 million year old Australopithecus robustus adult with a supernumerary tooth between the right first and second incisors [46]. Other remarkable reports of supernumerary teeth are that of a middle-aged Chalcolitic male with a supernumerary distomolar in the mandible [47] and that of a young adult woman from the Upper Paleolithic who presented with a right maxillary supernumerary molar [48]. Another study, concerning the CT scan of mummies from the Graeco-Roman Period, found two supernumerary teeth in the premaxillae region of a child [49]. Additionally, a syndromic individual from prehistoric Illinois, probably suffering from cleidocranial dysostosis, presenting with six supernumerary teeth, impacted teeth and dilacerated roots has been described in a study by Sacks [50].

Comparing the frequency of supernumerary teeth in ancient and present times would help to better understand this phenomenon and the phylogenetic process behind it and also gain more knowledge regarding the hypothesis that, with evolution, hypodontia becomes more frequent and that humans tend to have less teeth and smaller jaws.

Considering the low prevalence in present-day populations, one can reasonably assume it was low in the past as well.

\subsection{The Role of $C B C T$ in Paleoimaging}

Intraoral radiographic techniques, such as periapical and occlusal radiographs, have long been used for diagnostic purposes in dentistry. However, a correct diagnosis is sometimes impossible to achieve by using these techniques, mainly due to superimposing structural components. To overcome these shortcomings, more recently CBCT has been extensively used [31,51,52].

CBCT has been previously used in assessing archaeological samples [53,54], or for forensic purposes [55], mostly for the study of bone and dentition [56].

CBCT in studying ancient human remains has been limitedly used so far, despite the important role of diagnostic imaging (paleoimaging) in paleopathology and anthropology $[57,58]$. Multi-Slice Computed Tomography (MSCT) has proved its place in paleoimaging, whereas $\mathrm{CBCT}$, despite its advantages, is still not widely used as an imaging technique for the study of ancient bone remains [59].

According to available literature data, to date, several papers reported the use of CBCT for paleopathological studies, describing diseases or malformations.

The study of Ceperuelo et al. [47] documented a case of hyperdontia using CBCT, namely a mandibular supernumerary distomolar in the mandible of a Chalcolithic male from Spain.

Kendall et al. [60] used CBCT to provide a differential diagnosis of an exostotic bony lesion within the left maxillary sinus of a Romano-British (3rd-4th centuries AD) adult male from Newport, Lincoln. The conclusion was that, more likely, the lesion was of odontogenic origin. 
The case of dwarfism-related skeletal dysplasia in a Late Joseon Dynasty (South Korean) individual was reported by Woo et al. [61]. In this case, CBCT was used to scan the available cranial fragments, in order to obtain a 3D reconstructed image.

Giuffra et al. [62] explored the skeletal remains of an individual, dating to the 10th-12th century AD from the parish church of S. Pietro in Pava, Siena, Italy, presenting multiple osteomata on the skull and long bones. CBCT confirmed that the lesions consisted of compact bone, supporting the diagnosis.

Gaeta et al. [63] reported the use of CBCT in assessing the Italian mummy of Girolamo Macchi, dating from 18th century. The scan revealed that he suffered from atherosclerosis, affecting the abdominal arteries. For this reason, the arteries presented multiple calcifications, allowing to validly employ CBCT.

Izzeti et al. [59] used CBCT for studying an ancient child mandible discovered in an archaeological site in Northern Italy and made a comparison with MSCT in paleoimaging, emphasizing its role in imaging studies of ancient bone remains and encouraging its broader application in studying archaeological samples.

Based on the available literature data, CBCT represents a useful paleoimaging tool, for assessing mineralized human remains.

\subsection{The "Individual 1" Case}

The literature concerning crania and dentition studies of historical populations usually brings forward specimens presenting with severe dental wear, alveolar resorbtion, caries, linear enamel hypoplasia (LEH) and ante mortem tooth loss (AMTL) which are all quite common. There are still a number of dental pathologies that arise more frequently in more distant periods, such as excessive tooth wear and alveolar bone resorbtion, whereas in more recent times, probably because of the impact of agriculture and a softer diet, caries tend to be more frequent, as well as periapical lesions and AMTL [46,64-71]. To our knowledge, so far, the oldest specimen of a human jaw presenting a mesiodens is that of a 13,000 year old skull with a mesiodens present in the vault of the palate [72]. Other reports of mesiodens in the literature come from later periods, such as the Middle Iron Age in Scotland, approximately 250-410 AD [73], the Medieval Age, belonging to human remains found in Norway [74,75] and the 7th century in Germany [14].

The previous literature findings dealing with ancient teeth and the analysis of the "Individual 1" jaws have proven to be coincident.

Calculus deposits, attrition facets and periodontal disease are all common findings for that period of time $[67,68]$ but overall, it appears that "Individual 1"presented with a good masticatory function and a reasonably good oral health. None of our findings suggest any impediment to the person's capacity to eat, which, in those days, was probably the most important factor to consider.

The occlusion, as well, follows the general pattern of occlusion seen in most ancient jaws, that is a normal occlusion, with almost perfect intercuspation, except for the increased overjet. Also, the form of the mesiodens is in accordance with the literature regarding mesiodentes in present times $[8,10,19,76,77]$. According to the anthropological report, the individual presenting with the mesiodens was male, which also coincides with the data from the literature, mesiodentes being more frequently present in males [78].

By comparing the mesiodistal crown dimensions of the Eneolithic "Individual 1" to present-day populations, it can be concluded that the crown dimensions are very similar (Table 4). The types of populations considered for comparison were Indo-European [79]. Thus, although his stature was rather small $(159.2 \pm 4.32 \mathrm{~cm})$, the dimensions of his teeth are close to those of present-day population. 
Table 4. Mesio-distal dimensions of crowns (in $\mathrm{mm}$, for males and females) for various present-day populations compared to the teeth of "Individual 1".

\begin{tabular}{cccc}
\hline Subject Gender & & UR3 & LR3 \\
\hline “Individual 1" & $\mathrm{M}$ & 7.96 & 7.11 \\
\hline Greeks & $\mathrm{M}$ & 8.04 & 7.17 \\
& $\mathrm{~F}$ & 7.74 & 6.83 \\
\hline Turks & $\mathrm{M}$ & 7.89 & 6.95 \\
& $\mathrm{~F}$ & 7.49 & 6.58 \\
\hline Indians & $\mathrm{M}$ & 7.84 & 6.84 \\
& $\mathrm{~F}$ & 7.51 & 6.47 \\
\hline
\end{tabular}

Table 5 compares the mesio-distal crown dimensions of "Individual 1" to presentday controls from the literature [80] with and without supernumeraries, and reveals that the dimensions of all compared teeth of "Individual 1" are closer to the control group that presented supernumerary teeth. This is consistent with Brook's and Khalaf's findings regarding the fact that patients with supernumerary teeth tend to have larger tooth dimensions [81].

Table 5. Mesio-distal crown dimensions (in $\mathrm{mm}$ ) of "Individual 1" compared against data from the literature, i.e., permanent teeth in present-day patients with and without supernumeraries $[64,69]$.

\begin{tabular}{cccc}
\hline Subject & U1 & U3 & L3 \\
\hline “Individual 1” & 9.13 & 7.96 & 7.11 \\
\hline Controls with supernumeraries & 9.05 & 8.01 & 7.06 \\
\hline Controls without supernumeraries & 8.68 & 7.84 & 6.89 \\
\hline
\end{tabular}

However, a statistically relevant comparison between the dimensions shown in these tables cannot be made, as the dimensions of the teeth of an Eneolithic individual are being compared to mean values of teeth belonging to modern populations.

Reports from the literature show that the most frequent complications associated with supernumerary teeth is root resorption of the adjacent teeth and delayed or failure of eruption of the adjacent teeth $[8,24,77]$. We have no indication as to whether the eruption of the central incisors was delayed or not, but there is clearly no root resorption associated, as the root of the central incisor present is intact (Figures 6 and 7).

Based on the analysis of the jaws and the dental arches, using the modern CBCT threedimensional imaging technique, which enables a high-quality study of the maxillofacial bone and dental structures [31], it may be stated that, in the case of "Individual 1", the mesiodens seems to have been quite harmoniously integrated in the masticatory system, without causing any major disturbance to the alignment of teeth or to the occlusion. The only abnormality noted caused by the mesiodens was an increased overjet. Additionally, the mesiodens itself had no space to erupt in a normal position, so it was rotated by 90 degrees.

\section{Conclusions}

According to the scientific literature, the mesiodens is an anomaly found throughout all historical periods, from the oldest archaeological sites to present days. The approximately 5500 year old, well preserved human jaws of "Individual 1" bring forward another proof of developmental anomalies from the past, which makes them relevant to discussions regarding ancient oral pathology, placing this old subject in a new perspective. In this view, the presence of any supernumerary teeth in old crania is of great importance in enabling creating a database to compare the frequency and pattern of this pathology in ancient versus modern times. 
Author Contributions: Conceptualization, L.M.B., D.M. and L.C.R.; methodology, L.M.B. and S.P.; software, L.C.A.; investigation, B.A.C. and S.P.; resources, B.A.C.; data curation, L.M.B., B.A.C. and L.C.R.; writing-original draft preparation, L.M.B., B.A.C., S.P., D.M. and L.C.A.; writing-review and editing, L.C.A., L.C.R. and L.M.B.; supervision, D.M., L.C.A. and L.C.R. All authors have read and agreed to the published version of the manuscript.

Funding: This research received no external funding.

Institutional Review Board Statement: Not applicable.

Informed Consent Statement: Not applicable.

Conflicts of Interest: The authors declare no conflict of interest.

\section{References}

1. Pearce, M. The 'Copper Age'-A History of the Concept. J. World Prehistory 2019, 32, 229-250. [CrossRef]

2. Stratton, S. Burial and Identity in the Late Neolithic and Copper Age of South-East Europe. Ph.D. Thesis, Cardiff University, Cardiff, Wales, 2016.

3. Mallory, J.P.; Adams, D.Q. (Eds.) Encyclopedia of Indo-European Culture; Fitzroy Dearborn Publishers: London, UK; Chicago, IL, USA, 1997.

4. Jochim, M. The Lower and Middle Palaeolithic. In European Prehistory; Milisauskas, S., Ed.; Springer Science \& Business Media: Berlin/Heidelberg, Germany, 2012; pp. 15-54.

5. Raczky, P.; Siklósi, Z. Reconsideration of the Copper Age chronology of the eastern Carpathian Basin: A Bayesian approach. Antiquity 2013, 87, 555-573. [CrossRef]

6. Diaconescu, D. Consideraţii Privind Cronologia Epocii Timpurii a Cuprului în Estul Bazinului Carpatic (Cultura Tiszapolgár). Available online: https:/ /scholar.google.com/citations?view_op=view_citation\&hl=en\&user=mZeUHyIAAAAJ\&citation_for_ view =mZeUHyIAAAAJ:9yKSN-GCBOIC (accessed on 23 August 2020).

7. Sava, V. Neolithic and Eneolithic in the Lower Mures Basin; Mega Publishing House: Cluj-Napoca, Romania, $2015 ;$ p. 89.

8. Rajab, L.D.; Hamdan, M.A.M. Supernumerary teeth: Review of the literature and a survey of 152 cases. Int. J. Paediatr. Dent. 2002, 12, 244-254. [CrossRef] [PubMed]

9. Indira, M.D.; Dhull, K.S.; Sujartha, R.; Kumar Ps, P.; Devi Bm, G. Molariform mesiodens in primary dentition: A case report. J. Clin. Diagn. Res. 2014, 8, 33-35. [CrossRef]

10. Scheiner, M.A.; Sampson, W.J. Supernumerary teeth: A review of the literature and four case reports. Aust. Dent. J. 1997, 42, 160-165. [CrossRef] [PubMed]

11. Fernández Montenegro, P.; Valmaseda Castellón, E.; Berini Aytés, L.; Gay Escoda, C. Retrospective study of 145 supernumerary teeth. Med. Oral Patol. Oral Cir. Bucal. 2006, 11, 240-245.

12. Mossaz, J.; Kloukos, D.; Pandis, N.; Suter, V.G.A.; Katsaros, C.; Bornstein, M.M. Morphologic characteristics, location, and associated complications of maxillary and mandibular supernumerary teeth as evaluated using cone beam computed tomography. Eur. J. Orthod. 2014, 36, 708-718. [CrossRef]

13. Ramesh, K.; Venkataraghavan, K.; Kunjappan, S.; Ramesh, M. Mesiodens: A clinical and radiographic study of 82 teeth in 55 children below 14 years. J. Pharm. Bioallied Sci. 2013, 5 (Suppl. 1), 60-62. [CrossRef] [PubMed]

14. Meighani, G.; Pakdaman, A. Diagnosis and management of supernumerary (mesiodens): A review of the literature. J. Dent. (Tehran) 2010, 7, 41-49.

15. Orhan, A.I.; Ozer, L.; Orhan, K. Familial occurrence of nonsyndromal multiple supernumerary teeth. A rare condition. Angle Orthod. 2006, 76, 891-897. [CrossRef]

16. Inchingolo, F.; Tatullo, M.; Abenavoli, F.M.; Marrelli, M.; Inchingolo, A.D.; Gentile, M.; Inchingolo, A.M.; Dipalma, G. Nonsyndromic multiple supernumerary teeth in a family unit with a normal karyotype: Case report. Int. J. Med. Sci. 2010, 7, 378-384. [CrossRef]

17. Zhu, J.F.; Marcushamer, M.; King, D.L.; Henry, R.J. Supernumerary and congenitally absent teeth: A literature review. J. Clin. Pediatr. Dent. 1996, 20, 87-95.

18. Türkkahraman, H.; Yılmaz, H.H.; Çetin, E. A non-syndrome case with bilateral supernumerary canines: Report of a rare case. Dentomaxillofac. Radiol. 2005, 34, 319-321. [CrossRef]

19. Parolia, A.; Kundabala, M.; Dahal, M.; Mohan, M.; Thomas, M.S. Management of supernumerary teeth. J. Conserv. Dent. 2011, 14, 221-224. [CrossRef] [PubMed]

20. Brook, A.H.; Griffin, R.C.; Smith, R.N.; Townsend, G.C.; Kaur, G.; Davis, G.R.; Fearne, J. Tooth size patterns in patients with hypodontia and supernumerary teeth. Arch. Oral Biol. 2009, 54 (Suppl. 1), 63-70. [CrossRef] [PubMed]

21. Brook, A.H. Multilevel complex interactions between genetic, epigenetic and environmental factors in the aetiology of anomalies of dental development. Arch. Oral Biol. 2009, 54 (Suppl. 1), 3-17. [CrossRef] [PubMed]

22. Van Buggenhout, G.; Bailleul-Forestier, I. Mesiodens. Eur. J. Med. Genet. 2008, 51, 178-181. [CrossRef]

23. Högström, A.; Andersson, L. Complications related to surgical removal of anterior supernumerary teeth in children. ASDC J. Dent. Child. 1987, 54, 341-343. [PubMed] 
24. Açıköz, A.; Açıkgöz, G.; Tunga, U.; Otan, F. Characteristics and prevalence of non-syndrome multiple supernumerary teeth: A retrospective study. Dentomaxillofac. Radiol. 2006, 35, 185-190. [CrossRef] [PubMed]

25. Buikstra, J.E.; Ubelaker, D.H. Standards for Data Collection from Human Skeletal Remains: Proceedings of a Seminar at the Field Museum of Natural History; Research Series, 1; Arkansas Archeological Survey: Fayetteville, AR, USA, 1994.

26. Lovejoy, C.O.; Meindl, R.S.; Pryzbeck, T.R.; Mensforth, R.P. Chronological metamorphosis of the auricular surface of the ilium: A new method for the determination of adult skeletal age at death. Am. J. Phys. Anthropol. 1985, 68, 15-28. [CrossRef]

27. White, T.; Folkens, P. The Human Bone Manual, 1st ed.; Academic Press Elsevier: Amsterdam, The Nedherlands, 2005; pp. 127-152.

28. Sjøvold, T. Estimation of stature from long bones utilizing the line of organic correlation. Hum. Evol. 1990, 5, 431-447. [CrossRef]

29. Gurler, G.; Delilbasi, C.; Delilbasi, E. Investigation of impacted supernumerary teeth: A cone beam computed tomograph (cbct) study. J. Istanb. Univ. Fac. Dent. 2017, 51, 18-24. [CrossRef]

30. Katheria, B.C.; Kau, C.H.; Tate, R.; Chen, J.W.; English, J.; Bouquot, J. Effectiveness of impacted and supernumerary tooth diagnosis from traditional radiography versus cone beam computed tomography. Pediatr. Dent. 2010, 32, $304-309$.

31. Nardi, C.; Vignoli, C.; Pietragalla, M.; Tonelli, P.; Calistri, L.; Franchi, L.; Preda, L.; Colagrande, S. Imaging of mandibular fractures: A pictorial review. Insights Imaging 2020, 11, 30. [CrossRef] [PubMed]

32. Townsend, G.; Harris, E.F.; Lesot, H.; Clauss, F.; Brook, A. Morphogenetic fields within the human dentition: A new, clinically relevant synthesis of an old concept. Arch. Oral Biol. 2009, 54 (Suppl. 1), 34-44. [CrossRef]

33. Al-Ani, A.H.; Antoun, J.S.; Thomson, W.M.; Merriman, T.R.; Farella, M. Hypodontia: An Update on Its Etiology, Classification, and Clinical Management. BioMed Res. Int. 2017, 2017, 9378325. [CrossRef] [PubMed]

34. Gomes, R.R.; Da Fonseca, J.A.C.; Paula, L.M.; Faber, J.; Acevedo, A.C. Prevalence of hypodontia in orthodontic patients in Brasilia, Brazil. Eur. J. Orthod. 2010, 32, 302-306. [CrossRef] [PubMed]

35. Fekonja, A. Hypodontia in orthodontically treated children. Eur. J. Orthod. 2005, 27, 457-460. [CrossRef]

36. Sharpe, P.T. Homeobox genes and orofacial development. Connect. Tissue Res. 1995, 32, 17-25. [CrossRef]

37. Mitsiadis, T.A.; Smith, M.M. How do genes make teeth to order through development? J. Exp. Zool. B Mol. Dev. Evol. 2006, 306, 177-182. [CrossRef]

38. Townsend, G.C.; Bockmann, M.; Hughes, T.; Brook, A. Genetic, Epigenetic and Environmental Influences on Human Tooth Number, Size and Shape. Odontology 2012, 100, 1-9. [CrossRef] [PubMed]

39. Vastardis, H. The genetics of human tooth agenesis: New discoveries for understanding dental anomalies. Am. J. Orthod. Dentofac. Orthop. 2000, 117, 650-656. [CrossRef]

40. Ercal, P.; Taysi, A.E. Third molar agenesis: Prevalence and Association with agenesis of other teeth in a Turkish population. Niger. J. Clin. Pract. 2020, 23, 392-397. [CrossRef] [PubMed]

41. Reshitaj, A.; Krasniqi, D.; Reshitaj, K.; Milosevic, S.A. Hypodontia, gender-based differences and its correlation with other dental clinical features in kosovar adolescents. Acta Stomatol. Croat. 2019, 53, 347-353. [CrossRef] [PubMed]

42. Mattheeuws, N.; Dermaut, L.; Martens, G. Has hypodontia increased in Caucasians during the 20th century? A meta-analysis. Eur. J. Orthod. 2004, 26, 99-103. [CrossRef] [PubMed]

43. Heuck Henriksson, C.; Andersson, M.E.M.; Møystad, A. Hypodontia and retention of third molars in Norwegian medieval skeletons: Dental radiography in osteoarchaeology. Acta Odontol. Scand. 2019, 77, 310-314. [CrossRef]

44. Forshaw, R. The Two Brothers: An enlightening study of ancient Egyptian teeth. Br. Dent. J. 2019, 226, 518-524. [CrossRef] [PubMed]

45. Benazzi, S.; Buti, L.; Franzo, L.; Kullmer, O.; Winzen, O.; Gruppioni, G. Report of three fused primary human teeth in an archaeological material. Int. J. Osteoarchaeol. 2010, 20, 481-485. [CrossRef]

46. Ripamonti, U.; Petit, J.C.; Thackeray, J.F. A supernumerary tooth in a 1.7 million-year-old Australopithecus robustus from Swartkrans, South Africa. Eur. J. Oral Sci. 1999, 107, 317-321. [CrossRef]

47. Ceperuelo, D.; Lozano, M.; Duran-Sindreu, F.; Mercadé, M. Supernumerary fourth molar and dental pathologies in a Chalcolithic individual from the El Mirador Cave site (Sierra de Atapuerca, Burgos, Spain). HOMO 2015, 66, 15-26. [CrossRef]

48. Villotte, S.; Ogden, A.R.; Trinkaus, E. Dental abnormalities and oral pathology of the pataud 1 upper paleolithic human. Bull. Mem. Soc. Anthropol. Paris 2018, 30, 153-161. [CrossRef]

49. Villa, C.; Davey, J.; Craig, P.J.G.; Drummer, O.H.; Lynnerup, N. The advantage of CT scans and 3D visualizations in the analysis of three child mummies from the Graeco-Roman Period. Anthropol. Anz. 2015, 72, 55-65. [CrossRef] [PubMed]

50. Sacks, L. Multiple supernumerary teeth in a likely syndromic individual from prehistoric Illinois. Arch. Oral Biol. 2018, 93, 100-106. [CrossRef]

51. De Vos, W.; Casselman, J.; Swennen, G.R. Cone-beam computerized tomography (CBCT) imaging of the oral and maxillofacial region: A systematic review of the literature. Int. J. Oral Maxillofac. Surg. 2009, 38, 609-625. [CrossRef]

52. Nematolahi, H.; Abadi, H.; Mohammadzade, Z.; Soofiani Ghadim, M. The Use of Cone Beam Computed Tomography (CBCT) to Determine Supernumerary and Impacted Teeth Position in Pediatric Patients: A Case Report. J. Dent. Res. Dent. Clin. Dent. Prospect. 2013, 7, 47-50. [CrossRef]

53. Rossi, M.; Casali, F.; Chirco, P.; Morigi, M.P.; Nava, E.; Querzola, E.; Zanarini, M. X-ray 3D Computed Tomography of Bronze Archaeological Samples. IEEE Trans. Nucl. Sci. 1999, 46, 897-903. [CrossRef] 
54. Morigi, M.P.; Casali, F.; Bettuzzi, M.; Bianconi, D.; Brancaccio, R.; Cornacchia, S.; Pasini, A.; Rosi, A.; Aldrovandi, A.; Cauzzi, D. CT investigation of two paintings on wood tables by Gentile da Fabriano. Nucl. Instrum. Methods Phys. Res. A 2007, 580, 735-738. [CrossRef]

55. Du, C.; Zhu, Y.; Hong, L. Age-related changes in pulp cavity of incisors as a determinant for forensic age identification. J. Forensic. Sci. 2011, 56, S72-S76. [CrossRef]

56. De Angelis, D.; Gibelli, D.; Gaudio, D.; Cipriani Noce, F.; Guercini, N.; Varvara, G.; Sguazza, E.; Sforza, C.; Cattaneo, C. Sexual dimorphism of canine volume: A pilot study. Leg. Med. (Tokyo) 2015, 17, 163-166. [CrossRef]

57. Demiralp, K.Ö.; Bayrak, S.; Orhan, M.; Alan, A.; Kurşun Çakmak, E.Ş.; Orhan, K. Anatomical characteristics of the lingual foramen in ancient skulls: A cone beam computed tomography study in an Anatolian population. Folia Morphol. 2018, 77, 514-520. [CrossRef] [PubMed]

58. Przystańska, A.; Lorkiewicz-Muszyńska, D.; Abreu-Głowacka, M.; Glapiński, M.; Sroka, A.; Rewekant, A.; Hyrchała, A.; Bartecki, B.; Żaba, C.; Kulczyk, T. Analysis of human dentition from Early Bronze Age: 4000-year-old puzzle. Odontology 2017, 105, 13-22. [CrossRef] [PubMed]

59. Izzetti, R.; Gaeta, R.; Caramella, D.; Giuffra, V. Cone-Beam Computed Tomography vs. Multi-Slice Computed Tomography in paleoiaging: Where we stand. HOMO 2020, 71, 63-72. [CrossRef] [PubMed]

60. Kendall, R.; Kendall, E.J.; Macleod, I.; Gowland, R.; Beaumont, J. An unusual exostotic lesion of the maxillary sinus from Roman Lincoln. Int. J. Paleopathol. 2015, 11, 45-50. [CrossRef] [PubMed]

61. Woo, E.J.; Lee, W.-J.; Hu, K.-S.; Hwang, J.J. Paleopathological Study of Dwarfism-Related Skeletal Dysplasia in a Late Joseon Dynasty (South Korean) Population. PLoS ONE 2015, 10, e0140901. [CrossRef]

62. Giuffra, V.; Minozzi, S.; Riccomi, G.; Naccarato, A.G.; Castagna, M.; Lencioni, R.; Chericoni, S.; Mongelli, V.; Felici, C. Multiple osteomata from medieval Tuscany, Italy (ca. 10th-12th AD). Int. J. Paleopathol. 2019, 25, 56-61. [CrossRef] [PubMed]

63. Gaeta, R.; Fornaciari, A.; Izzetti, R.; Caramella, D.; Giuffra, V. Severe atherosclerosis in the natural mummy of Girolamo Macchi (1648-1734), "major writer" of Santa Maria della Scala Hospital in Siena (Italy). Atherosclerosis 2018, 280, 66-74. [CrossRef] [PubMed]

64. Carlson, D.S.; Van Gerven, D.P. Masticatory function and post-Pleistocene evolution in Nubia. Am. J. Phys. Anthropol. 1977, 46, 495-506. [CrossRef] [PubMed]

65. Papagrigorakis, M.J.; Synodinos, P.N.; Baziotopoulou-Valavani, E. Dental status and orthodontic treatment needs of an 11-year-old female resident of Athens, 430 BC. Angle Orthod. 2008, 78, 152-156. [CrossRef]

66. Alrousan, M.; Estebaranz-Sánchez, F.; Al-Shorman, A.; Martínez, L.M.; Gharaibeh, N.; Otum, K.; Pérez-Pérez, A. Buccal dental microwear as an indicator of dietary habits and dietary adaptation of the Byzantine people of Jordan. Anthropol. Anz. 2019, 76, 352-362. [CrossRef]

67. Sperduti, A.; Giuliani, M.R.; Guida, G.; Petrone, P.P.; Rossi, P.F.; Vaccaro, S.; Frayer, D.W.; Bondioli, L. Tooth grooves, occlusal striations, dental calculus, and evidence for fiber processing in an Italian eneolithic/bronze age cemetery. Am. J. Phys. Anthropol. 2018, 167, 234-243. [CrossRef]

68. Tomczyk, J.; Zalewska, M. Mechanical and chemical dental wear in historical population from the Syrian lower Euphrates valley. Arch. Oral Biol. 2016, 62, 49-57. [CrossRef] [PubMed]

69. Fuss, J.; Uhlig, G.; Böhme, M. Earliest evidence of caries lesion in hominids reveal sugar-rich diet for a middle miocene dryopithecine from Europe. PLoS ONE 2018, 13, e0203307. [CrossRef] [PubMed]

70. Lacy, S.A. The oral pathological conditions of the Broken Hill (Kabwe) 1 cranium. Int. J. Paleopathol. 2014, 7, 57-63. [CrossRef] [PubMed]

71. Munoz, O. Transition to agriculture in South-Eastern Arabia: Insights from oral conditions. Am. J. Phys. Anthropol. 2017, 164, 702-719. [CrossRef] [PubMed]

72. Sutton, P.R. Tooth eruption and migration theories: Can they account for the presence of a 13,000-year-old mesiodens in the vault of the palate? Oral Surg. Oral Med. Oral Pathol. 1985, 59, 252-255. [CrossRef]

73. Ives, R. An unusual double supernumerary maxillary mesiodens in a Middle Iron Age skeleton from South Uist, Western Isles, Scotland. Arch. Oral Biol. 2014, 59, 625-630. [CrossRef] [PubMed]

74. Hurlen, B.; Humerfelt, D. Hyperdontia in 14th-18th century Norwegian populations: A radiographic study on skulls. Dentomaxillofac. Radiol. 1984, 13, 135-139. [CrossRef]

75. Stermer Beyer-Olsen, E.M. Premaxillary hyperdontia in medieval Norwegians: A radiographic study. Dentomaxillofac. Radiol. 1989, 18, 177-179. [CrossRef] [PubMed]

76. Aoun, G.; Nasseh, I. Mesiodens within the Nasopalatine Canal: An Exceptional Entity. Clin. Pract. 2016, 6, 903. [CrossRef] [PubMed]

77. Chalakkal, P.; Krishnan, R.; De Souza, N.; Da Costa, G.C. A rare occurrence of supplementary maxillary lateral incisors and a detailed review on supernumerary teeth. J. Oral Maxillofac. Pathol. 2018, 22, 149. [CrossRef]

78. Brook, A.H.; O’Donnell, M.B.; Hone, A.; Hart, E.; Hughes, T.E.; Smith, R.N.; Townsend, G.C. General and craniofacial development are complex adaptive processes influenced by diversity. Aust. Dent. J. 2014, 59 (Suppl. 1), 13-22. [CrossRef] [PubMed]

79. Da Silva, P.R.; Lopes, M.C.; Martins-Filho, I.E.; Haye Biazevic, M.G.; Michel-Crosato, E. Tooth crown mesiodistal measurements for the determination of sexual dimorphism across a range of populations: A systematic review and meta-analysis. J. Forensic Odontostomatol. 2019, 37, 2-19. [PubMed] 
80. Khalaf, K.; Robinson, D.L.; Elcock, C.; Smith, R.N.; Brook, A.H. Tooth size in patients with supernumerary teeth and a control group measured by image analysis system. Arch. Oral Biol. 2005, 50, 243-248. [CrossRef] [PubMed]

81. Khalaf, K.; Smith, R.N.; Elcock, C.; Brook, A.H. Multiple crown size variables of the upper incisors in patients with supernumerary teeth compared with controls. Arch. Oral Biol. 2009, 54 (Suppl. 1), 71-78. [CrossRef] [PubMed] 